Chem. Chem. Technol., 2021,

Vol. 15, No. 4, pp. 486-492

Chemistry

\title{
THE FEATURES OF RHEOLOGICAL AND TRIBOLOGICAL BEHAVIOR OF HIGH-VISCOSITY POLYOLEFINE COMPOSITIONS DEPENDING ON THEIR CONTENT
}

\author{
Mykhailo Bratychak Jr ${ }^{1, \otimes}$, Victoria Zemke ${ }^{1,}$ Natalia Chopyk ${ }^{1}$
}

https://doi.org/10.23939/chcht15.04.486

\begin{abstract}
The influence of additive nature as well as its ratio on the rheological, tribological and technological properties of blends based on ultra-high molecular weight polyethylene has been determined. The energy costs impact in the polymer blends processing has been studied. It is shown that the rheological and tribological properties of the samples have a complicated dependence, which is determined by inhomogeneity of the system. The paper takes into consideration the influence of the friction coefficient of material and the viscosity of its melt on energy costs during processing by injection molding or extrusion.
\end{abstract}

Keywords: ultra-high molecular weight polyethylene (UHMWPE), energy balance, melt fluidity index, melt, rheological behavior, friction coefficient, tribological properties.

\section{Introduction}

With extending of application range of the polymer materials and the complication of their operation conditions, it is increasingly important to create materials of specified properties. The problem solution is possible through the synthetization of new ones or modifying existing polymers. The growing shortage of materials that meet the demands (increasing strength and ductility, toughness and other parameters) in the field of engineering, energy and chemical engineering represents a significant problem of the modern materials science. It is also worth mentioning that currently there is a need in replacing steel and non-ferrous metal products with polymer ones due to the fact that metals are subject to corrosion and have a high friction coefficient.

The largest group of industrial thermoplastics is polyolefins, which are the basis of many compositions [1-

\footnotetext{
${ }^{1}$ Lviv Polytechnic National University,

12, St. Bandera St., Lviv, 79013, Ukraine

mmbratych@gmail.com

(C) Bratychak Jr M., Zemke V., Chopyk N., 2021
}

3]. One of the promising polyolefins that meets the mentioned requirements is ultra-high molecular weight polyethylene. Polyethylene is applied in the compositions due to its considerable range of valuable properties: high impact strength, non-toxicity, resistance to aggressive environments, and the ability to retain properties in a wide diapason of compositions. Ultra-high molecular weight polyethylene cannot claim the scope of traditional brands of polyethylene, but its above-mentioned unique properties attract attention in view of its application as a polymer matrix in composites [4], as well as make it a perspective material in structural composite materials [5].

In technological aspect the UHMWPE processing is difficult due to the high viscosity of its melt. The material does not pass into the viscous liquid state even at a temperature higher than the melting point of its crystalline phase and stays in deformation-elastic state. The existing methods of UHMWPE processing are quite difficult technologically and energy consuming.

In the synthesis of linear ultra-high molecular weight polyethylene, the transitional batches are obtained. The last ones are characterized by considerably low melt fluidity $\left(\mathrm{MFI}_{2.16}=0.024 \mathrm{~g} / 10 \mathrm{~min}\right)$, that makes it difficult to process it via the most common methods such as injection molding and extrusion, even at the maximum equipment drive.

The main task was to develop the compositions based on UHMWPE which could be processed by industrial methods while maintaining the complex of working characteristics typical for ultra-high molecular weight polyethylene.

\section{Experimental}

\subsection{Materials}

Ultra-high molecular weight polyethylene (UHMWPE) of the DFDA 7047 brand: density $(\rho) 920$ $950 \mathrm{~kg} / \mathrm{m}^{3}$; melt flow index (MFI) $0.024 \mathrm{~g} / 10 \mathrm{~min}$; melting point $408 \mathrm{~K}$; tensile yield strength $18 \mathrm{MPa}$; relative elongation at tension $100 \%$. 
Low density polyethylene (LDPE) of 15803-020 brand: density $(\rho) 900-939 \mathrm{~kg} / \mathrm{m}^{3}$; melt flow index (MFI) $1.97 \mathrm{~g} / 10 \mathrm{~min}$; melting point $378-398 \mathrm{~K}$; tensile yield strength $6.8-13.7 \mathrm{MPa}$; relative elongation at tension $160 \%$.

High density polyethylene (HDPE) of 21008-075 brand: density $(\rho)$ 948-959 kg/m ${ }^{3}$; melt flow index (MFI) $6.4 \mathrm{~g} / 10 \mathrm{~min}$; melting point $403-418 \mathrm{~K}$; tensile yield strength $19-26 \mathrm{MPa}$; relative elongation at tension $105 \%$.

Polypropylene (PP) of 21060 brand: density $(\rho)$ 900-910 kg/m ; melt flow index (MFI) $12.52 \mathrm{~g} / 10 \mathrm{~min}$; melting point $433-446 \mathrm{~K}$; tensile yield strength $27-$ $35 \mathrm{MPa}$; relative elongation at tension $18 \%$.

\subsection{Blends Preparation}

The polymer mixture for testing was derived by melting the previously obtained mechanical mixture in a plunger injection cylinder of vertical type at $T=463 \mathrm{~K}$ for 15 min with the following pushing of melt through the nozzle $(d=2.095 \pm 0.005 \mathrm{~mm}, l=7 \mathrm{~mm})$. The obtained cooled rod was ground using a rotary-knife device. Then, the obtained granular mixture was loaded into a Kuasy $25 \times 32$ II $/ 1$ injection molding machine (Germany) (injection volume per cycle $25 \mathrm{~cm}^{3}$, screw speed $20 \mathrm{rpm}$, auger diameter $32 \mathrm{~mm}$ ). Mixing in plasticizer of the injection molding machine was carried out at the temperature of 463,473 and $493 \mathrm{~K}$ in the cylinder zones for $90 \mathrm{~s}$ to obtain a more homogeneous system. Then, by injection into the form at $T_{f}=323-343 \mathrm{~K}$ the samplesblades were obtained which were later used for the testing.

\subsection{Methods}

Determination of the melt flow index of initial polymers and their mixtures was performed applying the IIRT device according to ISO 1133-76 [6].

Based on the method of melt flow index determination, the study of the rheological behavior of mixtures depending on the type of polymer at different temperatures and pressures has been conducted. Capillaries with different $l / d$ ratio (length to diameter) were installed in extrusion chamber of the IIRT device and gradually changed from a smaller to a larger ratio during operation. The dependence of the volume flow rate of the polymer through the capillary, $Q=f(P)$, was measured at different loads. The load was also changed from lower to higher $[6,13]$.

Volumetric flow was determined by the weight of the specimens as the arithmetic mean of five determinations. Based on experimental data, we calculated:

1. The pressure made by the piston on the material (MPa):

$$
P_{i}=\frac{40 \times G_{i}}{\pi \times D^{2}}
$$

where $P$ is the piston pressure, $\mathrm{N} / \mathrm{m}^{2} ; G$ is a weight of cargo, which was chosen in the range of $1.95-9.83, \mathrm{~kg} ; D$ is the diameter of the piston device $(0.0095 \mathrm{~m})$.

2. Material consumption $\left(\mathrm{m}^{3} / \mathrm{s}\right)$ was determined from Eq. (2):

$$
Q_{i}=\pi \times r^{2} \times h_{i}
$$

where $r$ is the cylinder radius, $\mathrm{m} ; h$ is the stationary lowering velocity of the piston, $\mathrm{m} / \mathrm{s}$.

Based on the obtained results, we plotted the dependence $Q=f(P)$ for $l / d=$ const for the different capillaries. According to the above dependence, several values of $Q=$ const were found for several $P_{i}$, on the basis of which the dependence $\Delta P=f(l / d)$ was constructed. Extrapolating the dependence to zero value of the pressure drop, we obtained the input correction $\left(n_{b}\right)$, expressed in the relative lengths of the channel.

Friction coefficient determination for ultra-high molecular weight polyethylene as well as its blend was conducted according to IEC TR 60648:1979 [7].

\subsection{Heat Balance}

For the theoretical analysis of the zone the following equation of heat balance was used $[8,10]$ :

$$
E_{r}-E_{l}+E_{w}+\Delta E_{m}+E_{c}-Q_{k, r}=0
$$

where $E_{r}$ is the energy required to rotate the worm; $E_{l}$ is the energy of the worm at the end of the zone; $E_{w}$ is the heating energy of the zone; $\Delta E_{m}$ is the change in the internal energy of the material; $E_{c}$ is the energy lost with water for cooling; $Q_{k . r}$ is the heat consumption by the cylinder due to convection and radiation; $\left(\Delta E_{r}-E_{l}\right)=\Delta E_{l}$ is the energy supplied to the material from the main drive of the worm and can be determined by changes in torque at the inlet and outlet of the site and the angular velocity of rotation of the worm $\omega$ :

$$
\Delta E_{l}=\left(M_{1}-M_{2}\right) \cdot \omega=\Delta M \cdot \omega
$$

The torque that occurs on the auger during transportation was calculated from Eq. (5) [9]:

$$
\begin{aligned}
\Delta M= & \frac{P_{1}-P_{2}}{\ln P_{1} / P_{2}} \cdot C_{1} \cdot f_{S}\left[C_{2}+\left(f_{C} \cdot \cos \varphi+\right.\right. \\
& \left.\left.+\frac{f_{C}}{f_{S}} \cdot \sin \varphi\right) \cdot C_{3} \cdot \sin \left(\omega_{m}+\varphi\right)\right]
\end{aligned}
$$

where $P_{1}, P_{2}$-is a pressure at inlet and outlet of the zone, respectively; $C_{1}, C_{2}, C_{3}$ are geometric constants; $\varphi$ is an angle of inclination of the helical line of the worm; $\omega_{m}$ is an average feed angle; $f_{s}, f_{c}$ is a friction coefficient of the wall of the worm and the cylinder, respectively. $[9,11]$ :

The equation for the pressure profile is as follows 


$$
\begin{gathered}
P_{\mu+1}=\left(m_{\mu}-\frac{B_{3}-K \times A_{3}}{B_{3}-K \times A_{1}}\right) \times \exp \left(\frac{B_{1}-K \times A_{1}}{B_{2}-K \times A_{2}}\right) \times \Delta Z_{\mu}+ \\
+\left(\frac{B_{3}-K \times A_{3}}{B_{1}-K \times A_{1}}\right)
\end{gathered}
$$

where

$\mathrm{A}_{1}=f_{B} \cdot \kappa_{B} \cdot \omega \cdot \sin \theta-\bar{\omega} \cdot \mathrm{A} \cdot \sin \varphi+2 \cdot \kappa_{F} \cdot H \cdot f_{S} \cdot \sin \varphi+$

$+\kappa_{S} \cdot \omega_{S} \cdot \sin \varphi \cdot\left(1+\mathrm{A} / f_{S}\right)$

$\mathrm{A}_{2}=H \cdot \bar{\omega} \cdot \sin \varphi$

$\mathrm{A}_{3}=\frac{2 \cdot Q^{2} \cdot \mathrm{A} \cdot \sin \varphi}{H^{2} \cdot \bar{\omega} \cdot \rho}$

$\mathrm{B}_{1}=\kappa_{\% o} \cdot f_{\% o} \cdot \omega \cdot \cos \theta+\bar{\omega} \cdot \mathrm{A} \cdot \cos \varphi \bar{D} / D-2 \kappa_{F} \cdot H \cdot f_{F} \bar{D} / D^{\cos \varphi-}$

$-\kappa_{S} \cdot f_{S} \cdot \omega_{S}\left(1+\mathrm{A} / f_{S}\right) \cdot \frac{\bar{D}}{D} \cdot \cos \varphi$

$\kappa=\frac{\bar{D}}{D} \cdot \frac{\sin \varphi+f_{S} \cdot \cos \varphi}{\cos \varphi-f_{S} \cdot \sin \varphi}$

$\Theta$ is an angle of the polymer movement in the auger channel.

The remaining definitions correspond to those accepted in extrusion theory.

\section{Results and Discussion}

\subsection{Study of Blends Rheology}

Two rheological characteristics of materials are decisive in the technology of processing polymer mixtures: viscosity and elasticity. Understanding the relationship between rheological properties and molecular characteristics, on the one hand, and between rheological properties and processing conditions, on the other hand, it is necessary to optimize plastics processing technology, for example, to facilitate mixing of polymers to produce the final product of specified properties [12].

In given work the properties of ultra-high molecular weight polyethylene mixtures containing isotactic polypropylene, low-density polyethylene as well as high-density polyethylene were researched [13, 14]. The peculiarity of the research was the long-term mixing of the components (not less than $90 \mathrm{~s}$ ) in the preplasticizer of the injection molding machine, followed by the formation of standard samples of the melt in the mold. Studies of the UHMWPE mixture were performed in a wide range of compositions with percentage from 5 to 90 . Fig. 1 shows the dependence of MFI mixtures based on UHMWPE on the composition and additive nature.

The dependence of MFI mixtures of the similar composition prepared under condition of double mixing in screw plasticizer of molding machine on the composition and additive nature are presented in Fig. 2.

One can see from Figs. 1 and 2 that the introduction of additives into polymer composition containing UHMPE improves its fluidity compared with the original UHMWPE. Moreover, the increasing nature of fluidity with increasing content of the additive remains but appearance of the curves varies depending on conditions and mixing. The fluidity deviation from additivity for all three cases of blending in the content diapason up to 30 mass $\%$ is almost identical. The blend gets the most significant change in MFI in the case of mixing with PP. However, these changes depend on the mixing conditions, when during melting the MFI increases immediately with an addition of small amounts of PP during mixing, the increase is observed only after $30 \%$ of the additive content during mixing in the plasticizer. Instead, when LDPE and HDPE are added, an increase in MFI is observed after 70 mass $\%$ of additive content.

At the same time, for the same composition with double mixing (Fig. 2), the MFI decreases when the PP content is more than 50 mass \%. Therefore, the mixing conditions have a decisive influence on the fluidity of the blends $[15,17]$.

Thus, twice passing through a plasticizer with a mixing time of $90 \mathrm{~s}$ causes significant changes in the MFI for all compositions containing polymers - additives (Fig. 2 ). The change in MFI is being manifested in the different ways depending on the nature of additive, but the total increase is less than with a single plasticization (Fig. 1). For LDPE, significant increase in MFI is observed for the blend obtained by the second method with an increase in additive content in the composition after $70 \%$. Instead, the change in MFI depending on the amount of HDPE has a pronounced variable character with a minimum value at 80 mass $\%$ and a maximum at $40-45$ mass $\%$ of the HDPE content. When adding PP, an extreme dependence of MFI with the maximum at 50 mass $\%$ is observed. However, a clear difference between MFI of the obtained mixtures and MFI of the original polymers can be noted. At one-time plasticization, as well as at melting in the cylinder of plunger type, MFI of initial additives is higher than in blends. At the same time, double long-term plasticization with PP leads to higher values of MFI of mixtures than MFI of the plasticized PP. In the case of mixing with HDPE, an alternate increase and decrease in the values of the melt flow index is being observed.

Based on obtained results it can be concluded that at melting in the plunger cylinder, obviously, a mixture is obtained in which the medium is the melt of additive and UHMPE acts as a heterogeneous dispersed additive [18].

The decrease in values of MFI mixtures, although larger in relation to the original UHMPE, indicates a structural change in their structure. It can be foreseen that the elements of ultra-high molecular structure are "bound" to each other by the "transitional" macromolecules (more likely inter-penetration of additive into the polymer grid of UHMWPE) $[16,17]$. 


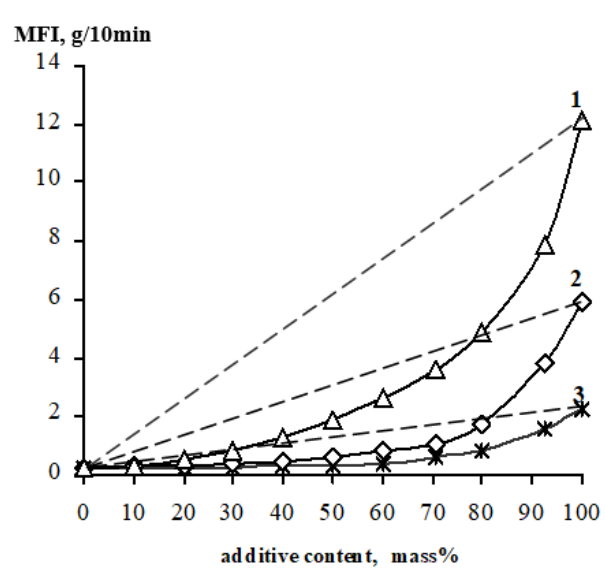

Fig. 1. Dependence of the melt flow index of mixtures based on UHMWPE on the composition and nature of additive: experimental (-); theoretical (- -)

Additives: PP (1); HDPE (2) and LDPE (3).

Derivation conditions: mixing in the screw plasticizer of the injection molding machine

Therefore, insufficient mixing (without shear stresses) - short-term shear during flow leads to the heterogeneous mixture formation and only with prolonged mixing (with the shear stresses) causes the dispersion of UHMWPE, and hence the formation of a more homogeneous mixture.

At the same time, it was found that not all of the mixtures obtained by blending in the screw plasticizer are technological and, therefore, cannot be applied, for example, for injection molding. These are mixtures based on UHMWPE with a content of PENG up to 60 mass \%, and HDPE and PP - up to 30 mass \%.

The authors found that for mixtures of UHMWPE containing PP yield strength changes with a change in composition without signs of synergism at $513 \mathrm{~K}$ and processing at $463 \mathrm{~K}$ causes a clear deviation from additivity. It is obvious that UHMPE can manifest itself in a mixture with PP as a conventional HDPE, despite much higher molecular weight.

Even more complicated property-composition dependences are displayed by the system of such seemingly chemically similar components as UHMWPE : LDPE. The pronounced S-shaped character of dependences curves of yield strength, especially for a blend containing HDPE attracts attention.

Thus, it is observed that the decrease in viscosity of the melt and its elasticity should cause a decrease in energy costs. In the processes of polymer processing the flow of melts in the channels of different shapes occurs. Rheological properties manifest themselves in different ways depending on the flow geometry.

Maximum homogeneity of mixtures is achieved when the components of the mixture are characterized by

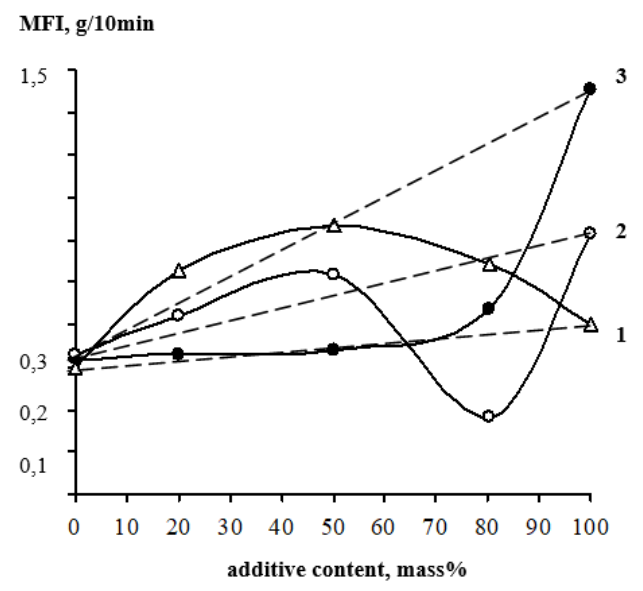

Fig. 2. Dependence of the melt flow index of mixtures based on UHMWPE on the composition and nature of additive: experimental (-); theoretical (- -)

Additives: PP (1); HDPE (2) and LDPE (3).

Derivation conditions: double mixing in the screw plasticizer of the injection molding machine

close values of the melt flow index (MFI) or their energy characteristics. This is important for predicting and evaluating the recyclability of polymer blends. Our polymer components have different values of MFI but are close in the amount of activation energy of the viscous flow [13].

Rheological behavior of the studied blends which affects the technological parameters of their processing in the work was carried out according to the above method (subsection 2.3). Initially, the change in volume flow $Q$ at flow from the content of additive in the mixture, as well as the pressure change for capillaries with different ratios of diameter to length $(l / d=3.4$ and 9.2) were determined at temperatures of 448, 463, and $493 \mathrm{~K}[11,13]$.

For the mixtures of UHMWPE/additive, the volume flow rate generally increases with increasing temperature and pressure. The obtained dependences in all cases have a variable character which is inherent in the structural transformation in the blends during mixing [19].

For PP mixtures at all values of temperature and $P=0.3 \mathrm{MPa}$, there is an extreme dependence of the volume flow rate on the PP content, moreover the extremum limits increase with increasing temperature. At the same time, for less ratio $l / d$ (3.4) with increasing pressure $(P=1.57 \mathrm{MPa})$ the volume flow extremum is leveled with increasing temperature. The same is observed at $P=1.57 \mathrm{MPa}$ for higher ratio $l / d(9.2)$.

For HDPE mixtures, the extreme dependence of the volume flow rate on the content of additive is fixed only for the temperature of $448 \mathrm{~K}$. At the same time, for mixtures with LDPE the $Q=f(x)$ the extremum is practically not observed regardless of the conditions of the process. Common factor for the compositions containing 
$\mathrm{PE}$ and $\mathrm{PP}$ is an increase in volume flow with increasing temperature for all studied ratios $l / d$. Exceptions are $\mathrm{PE}$ mixtures at the highest temperature and pressure.

Based on the obtained results the $Q=f(P)$ dependence was composed (Fig. 3) for the UHMWPE/ additive mixtures with the ratio of $1: 1$. As we can see, the volume flow increases with increasing pressure characterized by an almost rectilinear relationship. PP mixtures have the highest values. For all mixtures the highest $Q$ values are observed for the ratio $l / d=3.4$.

According to the dependence $Q=f(P)$, for several values of $Q=$ const the dependence $\Delta P=f(l / d)$ was predicted [13].

Extrapolation to zero pressure drop allowed to determine the value of inlet amendment. Inlet amendment for UHMWPE/LDPE mixtures is 4.7, for UHMWPE/ HDPE mixtures 2.5, for PP ones 0.9. As we can see, mixture melts containing PE cause a high value of the pressure drop, in our opinion, this is due to their high elasticity.

Thus, the pressure distribution with increasing volumetric flow becomes nonlinear due to the relaxation processes that are characteristic of viscoelastic fluids.

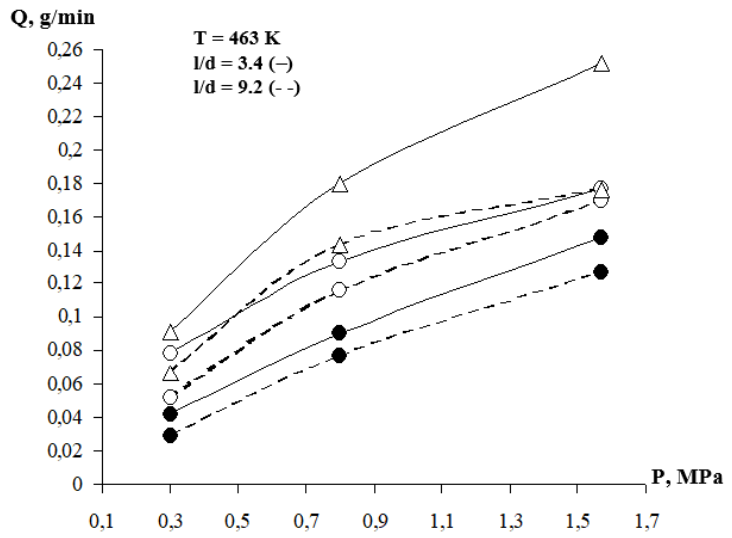

Fig. 3. The dependence of volume flow rate of the UHMWPE/additive mixture $(1: 1)$ on pressure and various ratio $l / d$ at $T=463 \mathrm{~K}$

Additives: $\operatorname{LDPE}(\bullet)$; $\operatorname{HDPE}(\mathrm{o})$ and $\operatorname{PP}(\Delta)$

\subsection{Analysis of Energy Balance}

The main task was to simulate the extrusion process and find necessary ratio of technological parameters that would provide a minimum load on the drive of extruder screw. There are a number of technological and economic problems which caused by application of the large extruders and injection molding machines with powerful plastic joints to process high viscosity polymer compositions. The paper combines theoretical and experimental studies on an extruder with a screw with the diameter of $45 \mathrm{~mm}[10,11]$.
As we can see, melts of PE mixtures cause high values of pressure drop, in our opinion due to their high elasticity, which in turn is the main factor in the growth of energy parameters of processing on equipment with screw plasticizer.

The effect of the friction coefficient during the processing of UHMWPE and its mixture containing 20 mass $\%$ of LDPE has been researched in the presented work [7].

As it is seen in Fig. 4, the curves of dependence of the change in the values of friction coefficient on the temperature of UHMWPE and its HDPE mixture are much lower than the values for pure HDPE. A lower melting point of HDPE and more increasing in the friction coefficient are smoothed in a mixture with UHMWPE.

Experimental data have shown that adding of LDPE into UHMWPE leads to a shift of the flow curves towards lower shear stresses, which is accompanied by a decrease in viscosity [17]. Therefore, it is impossible that such a significant difference in the temperature dependences of friction coefficient and viscosity does not affect the extrusion process, especially which concerns energy balance.

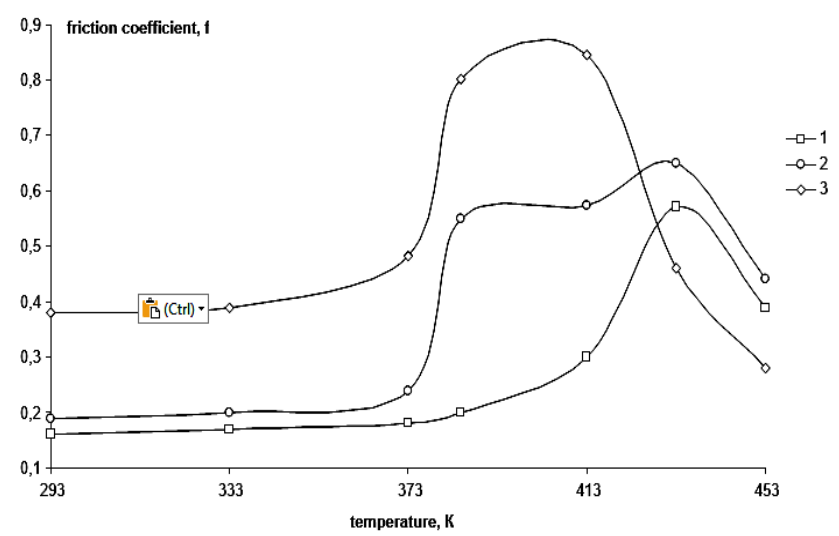

Fig. 4. Temperature dependences of the friction coefficient along the steel at pressure of $1 \mathrm{MPa}$ : UHMWPE (1); UHMWPE + 20\% HDPE (2) and HDPE (3)

It is known that extrusion is a complex process of polymer processing. The material in the worm extruders is transported by friction forces. The material moves in the auger channel like a "cork" with a gradual increase in its temperature to the melting point, obtaining heat from the thermal zones of the cylinder heating, as well as due to the heat of friction. The loading area determines the extruder operation the most, as it supplies up to $60 \%$ of capacity.The power supplied to the auger is partly converted into heat on the surface of the cylinder, the screws of the auger and its core and partly goes to create pressure. But most of it is dissipated in the form of heat on the surface of the cylinder (removed by cooling water, and 
partially - in the "cork"). As soon as the melting temperature of the polymer is reached, the forced movement by the mechanism of dry friction will pass into the forced flow by the mechanism of viscous friction.

Stability infringement of the drive can cause high costs due to fluctuations in the load on the auger and, as a consequence, its ability to transport. The power applied to the auger determines the torque and speed of its rotation and affects the energy costs during processing. All these factors are interrelated and primarily depend on the tribological and rheological properties of the processed materials. The power consumed by the extruder depends on the operation of the three zones of the auger: loading, melting, and dosing.

The change in internal energy $\Delta E_{m}$ was determined by the change in material enthalpy and extruder productivity. The values of the friction coefficient $f_{s}$ and the angle of motion $\Theta$ in the calculations are a function of temperature and distance $z$, their numerical values are determined at each section of the auger. The temperature profile along the axis of the auger channel is calculated based on the fact that the heating of the material in the auger channel occurs both due to heat from the heated walls of the cylinder and due to energy dissipation of the material due to friction.

The dependence of polymer friction coefficient on the temperature is nonlinear, so there is a need to control the conditions of full load on each section of the auger [20]. It was achieved considering that the calculated capacity of the loading area should not be less than the total capacity of the extruder.

Table 1 shows the values of dependence of energy supplied to the material on the main drive of $\Delta E_{r}$ auger, as well as the change in the internal energy of material $\Delta E_{m}$ and the energy dissipated with cooled water $\Delta E_{c}$ from the number of rotations of the extruder auger.

Table 1

\section{Dependence of $\Delta E_{\eta}, \Delta E_{\mu}$ and $\Delta E_{c}$ on the number} of the extruder auger rotations

\begin{tabular}{|c|c|c|c|}
\hline Indicators & \multicolumn{3}{|c|}{$\Delta E, \mathrm{~kW}$} \\
\hline$n, \mathrm{rev} / \mathrm{min}$ & $\Delta E_{r}$ & $\Delta E_{m}$ & $\Delta E_{c}$ \\
\hline 40 & 3.6 & 2.5 & 2.1 \\
\hline 60 & 3.8 & 3.1 & 2.3 \\
\hline 80 & 4.7 & 3.5 & 2.5 \\
\hline 90 & 6.2 & 3.9 & 2.6 \\
\hline
\end{tabular}

With an increasing of the rotation velocity of auger the power on its shaft increases while the specific increase in the internal energy of the polymer material remains almost constant. The portion of heat that goes with water for cooling may decrease slightly. Thus, considerably high pressure in the loading zone causes only additional energy consumption with water for cooling and has virtually no effect on the internal energy of the melt. In general, the energy efficiency increases with the increase in the number of rotations of the worm, which is especially noticeable at high productivity.

Studies show that the energy supplied to the material in the first thermal zone is only $10-13 \%$ of the total amount of energy supplied from the heating system of the cylinder.

Note that most of the energy (30-40\%) is wasted irreversibly with cold water. This indicates that increasing the productivity of the extruder via intensifying the cooling of the loading zone needs to be optimized [21]. At high pressures at the end of the worm occurring at high speeds the auger could completely eliminate the heating of the first zone and reduce the heat coming from the water.

The effect of melt pressure at the end of the auger $P_{m}$ at $100 \mathrm{rev} / \mathrm{min}$ on the main components of the heat balance is presented in Table 2. The pressure was determined discretely, dividing the entire channel into small sections within which the geometric parameters of the channel and the properties of the polymer were considered constant.

Table 2

Dependence of $\Delta E_{r}, \Delta E_{m}, \Delta E_{c}$ on melt pressure

\begin{tabular}{|c|c|c|c|}
\hline Indicators & \multicolumn{3}{|c|}{$\Delta E, \mathrm{~kW}$} \\
\hline$P_{m}, \mathrm{rev} / \mathrm{min}$ & $\Delta E_{r}$ & $\Delta E_{m}$ & $\Delta E_{c}$ \\
\hline 10 & 5.0 & 4.2 & 3.9 \\
\hline 20 & 5.1 & 4.3 & 4.0 \\
\hline 40 & 6.2 & 4.8 & 4.2 \\
\hline 60 & 6.9 & 5.1 & 4.4 \\
\hline
\end{tabular}

Notes: $n=100 \mathrm{rev}^{-1}$, cooling $500 \mathrm{l} / \mathrm{h}, t_{c . w}=291 \mathrm{~K}$

It should be noted that the decrease in the effective viscosity with increasing shear rate, leads to the fact that the values of the components of the heat balance increase noticeably. Since the increase in pressure $P_{m}$ spreads to the loading zone so with the pressure increasing, the amount of energy supplied to the material and removed from the zone with water increases too. However, the relative change in energy consumption with water decreases, which indicates the feasibility of processing highly viscous polymers at higher worm speeds and high melt pressures.

The value of $\Delta E_{m}$ varies insignificantly, so we can recommend periodic shutdown of the heating of the first thermal zone which will reduce the share of energy to be diverted away with water by $10-15 \%$.

\section{Conclusions}

In this manner the majority of double mixtures of polymers (UHMWPE/additive) have higher values of melt 
flow rate, compared with the original UHMWPE. The influence of the production conditions on the value of melt flow index of polymer blends is determined. At the same time, research conducted have shown that good dispersion of UHMWPE in the melt of polymers/ homologues requires great effort in conditions of high concentration of shear stresses to form, in a certain way, a homogeneous blend. When melting in the plunger cylinder the mixture being obtained, and the medium is the co-melt of the additive thus UHMWPE acts as a heterogeneous dispersed additive.

The rheological behavior of the studied blends, which affects the technological parameters of their processing has been studied. It is determined that melts of mixtures containing PE cause high values of pressure drop due to their high elasticity.

Determination of the magnitude of the input effect (input correction $n$ ) for mixtures could be used as a criterion for analyzing the nature of the flow. In this case, the nature contravention of the flow could lead to deterioration of the working properties of the product and changes in the process parameters (volume flow, pressure, torque of the auger).

On the basis of heat balance the theoretical analysis of changes of its components at processing of highly viscous material on the basis of UHMWPE is carried out. Despite the prediction of decreasing effective viscosity with increasing shear rate, the level of heat balance components increases markedly. Since the pressure Pm increase is extended to the loading zone, with the pressure increase therein the amount of energy supplied to the material and going away from the zone with water increases. However, the relative change in energy consumption with water decreases indicating the need to process highly viscous polymers at the higher auger speeds and high melt pressures.

Comparing the theoretical calculations with experimental data, the optimization of the technological processing mode applying the conventional extruders was realized, which eliminated the overload of the drive and the pulsation of the melt.

\section{References}

[1] Kurylo M., Suberlyak O., Zemke V.: Visnyk Lvivskoho Nats. Univ., 1999, 361, 111.

[2] Lipatov Yu.: Phiziko-Khimiya Mnogokomponentnykh

Polimernykh System. Naukova dumka, Kyiv 1986.

[3] Krasinskyi V., Suberlyak O., Zemke V. et al.: Chem. Chem. Technol., 2019, 13, 59. https://doi.org/10.23939/chcht13.01.059

[4] Parfit J., Jeykok M.: Khimiya Poverhnostey Razdela Phaz. Mir, Moskva 1984.

[5] Suberlyak O., Kurylo M., Zemke V.et al.: Materiały Polimerowe i ich Przetwórstwo, Częstochow 2000.
[6] ISO 1133-76: Standard Test Method for Melt Flow Rates of Thermoplastics by Extrusion Plastometer.

[7] IEC TR 60648:1979. Method of test for coefficients of friction of plastic film and sheeting for use as electrical insulation.

[8] Basov N., Kazankov Yu., Lyubartovich V.: Raschet i Konstryirovanie Oborydovania dlia Proizvodstva i Pererabotki Polimernykh Materialov. Khimiya, Moskva 1986.

[9] Pakharenko V. et al.: Teplophizicheskie i Pheologicheskie Kharakteristiki i Koefitsienty Treniya Napolnenykh Termoplastov. Naukova Dumka, Kyiv 1983.

[10] Mikulionok I.: Tekhnologichni Osnovy Pereroblennya Polimernykh Materialiv. KPI im. Igorya Sikorskogo, Kyiv 2020. https://ela.kpi.ua/bitstream/123456789/35084/1/Pereroblenniapolimernykh-materialiv_NavchPosib.pdf

[11] Avramenko V. et al.: Tekhnologiya Vyrobnytstva ta Pererobky Polimeriv Medyko-Biologichnogo Pryznachennya. Vyd-vo Tekhnologichnyj Tsentr, Kharkiv 2018.

https://repository.entc.com.ua/media/309126-technology-ofproduction-and-processing-ca9afa30.pdf

[12] Levytskyi V., Masyuk A., Katruk D. et al.: Chem. Chem. Technol., 2020, 4, 496. https://doi.org/10.23939/chcht14.04.496 [13] Kurylo M., Zemke V., Suberlyak O.: Visnyk Lvivskoho Nats. Univ., 2002, 447, 74.

[14] Miroshnikov Yu., Lemstra P., Letuchyj M. et al.:

Vysokomolekulyarnye Soedineniya, 2000, 7, 1200.

[15] Kalinchev E., Sakovtseva M.: Svoistva i pererabotka termoplastov. Khimiya, Leningrad 1983.

[16] Chang Dey Han: Reoligia v procesach pererabotki polimerov. Khimiya, Moskva 1979.

[17] Suberlyak O., Zemke V., Pronyk O.: Kompozitsionnye Materialy v Promyshlennosti, 2003, 107.

[18] Levytskyi V., Katruk D., Masyuk A. et al.: Chem. Chem. Technol., 2018, 12, 53. https://doi.org/10.23939/chcht12.01.053 [19] Suberlyak O., Bratychak Mykh., Zemke V., Chopyk N.: Chem. Chem. Technol., 2014, 8, 411.

https://doi.org/10.23939/chcht08.04.411

[20] Yurchenko M.: Narkovyi Visnyk NLTU Ukrainy, 2019, 29, 112. https://doi.org/10.15421/40290223

[21] Shved M., Shved D., Velikoivanenko S.: Molodyi Vchenyi, 2018, 1, 447. http://molodyvcheny.in.ua/ua/archive/53

Received: February 23, 2021 / Revised: March 15, 2021 / Accepted: April 12, 2021

\section{ОСОБЛИВОСТІ РЕОЛОГІЧНОЇ ТА ТРИБОЛОГІЧНОЇ ПОВЕДІНКИ ВИСОКОВ'ЯЗКІСНИХ ПОЛІМЕРНИХ КОМПОЗИЦІЙ В ЗАЛЕЖНОСТІ ВІД СКЛАДУ}

\footnotetext{
Анотація. Встановлено вплив природи доданків та їх співвідношення на реологічні, трибологічні та технологічні властивості сумішей на основі надвисокомолекулярного поліетилену. Вивчено їх вплив на енергетичні витрати в прочесі переробки полімерних сумімей. Показано, що реологічні та трибологічні властивості зразків мають характер залежсності складний, шо визначається неоднорідністю системи. В роботі враховано вплив коефіuіснта тертя метеріалу та в'язкості його розтопу на енергетичні витрати в процесі переробки методом лиття під тиском чи екструзією.

Ключові слова: надвисокомолекулярний поліетилен, енергетичний баланс, показник текучості розплаву, розплав, реологічна поведінка, коефічієнт тертя, трибологічні властивості.
} 